\title{
A TISZTESSÉGTELEN KERESKEDELMI GYAKORLATOK SZABÁLYOZÁSA ÉS JOGGYAKORLATA SZLOVÁKIÁBAN ${ }^{\mathrm{I}}$
}

\author{
MareK Maslák
}

Debreceni Jogi Mühely, 2020. ÉVI (XVII. ÉVfolyam) I-2. DOI I $0.24169 / \mathrm{DJM} / 2020 / \mathrm{I}-2 /$ IO

\section{A tisztességtelen kereskedelmi gyakorlatokról szóló irányelv átültetése a szlovák jogrendbe}

\begin{abstract}
A Szlovák Köztársaság a 2005/29/EK tisztességtelen kereskedelmi gyakorlatokról szóló irányelvet (a továbbiakban: 2005/29/EK irányelv) ${ }^{2}$ a Tt. ${ }^{3}$ 250/2007. számú, fogyasztóvédelemről szóló törvénnyel ültette át (a továbbiakban: SzFvt.). A SzFvt.-t módosító törvény (Tt. 102/2014. számú törvény) kiküszöbölte a 2005/29/EK irányelv végrehajtásának hiányosságait, és kiszélesítette a fogyasztók tisztességtelen kereskedelmi gyakorlatokkal szembeni védelmének lehetőségeit azáltal, hogy a törvény hatálya nem csupán ingó dolgokra (áruk), hanem szolgáltatásokra, ingatlanra, jogokra és kötelezettségekre is kiterjed.
\end{abstract}

\section{Az átlagfogyasztó fogalmának értelmezése a joggyakorlatban}

A SzFvt., csakúgy, mint a 2005/29/EK irányelv, az átlagfogyasztó és a kiszolgáltatott fogyasztó fogalmát is használja. Dobrovodský rámutat arra, hogy az átlagfogyasztót az adott ország lakosságához viszonyítva kell átlagosnak tekinteni. ${ }^{4} \mathrm{~A}$ bíróságok gyakran anélkül használják az átlagfogyasztó fogalmát, hogy különös figyelmet fordítanának tulajdonságaik értékelésére. Ezzel összefüggésben, a Szlovák Köztársaság Legfelsőbb Bírósága 8 Sžo/40/2011.

1 A tanulmány megírása és megjelentetése az Igazságügyi Minisztérium jogászképzés színvonalának emelését célzó programjai keretében valósult meg.

2 Az Európai Parlament és a Tanács 2005/29/EK irányelve (2005. május 11.) a belső piacon az üzleti vállalkozások fogyasztókkal szemben folytatott tisztességtelen kereskedelmi gyakorlatairól, valamint a 84/450/EGK tanácsi irányelv, a 97/7/EK, a 98/27/EK és a 2002/65/EK európai parlamenti és tanácsi irányelvek, valamint a 2006/2004/EK európai parlamenti és tanácsi rendelet módosításáról. HL L 149, 2005.6.11. 22-39.

3 a szlovák jogban a törvényeket hivatalosan is törvénytárba (továbbiakban: Tt.) sorolják, amelyre a törvény neve is utal, hasonlóan a régi magyar jogban egykor használatos törvénycikkekhez.

4 R. Dobrovodský: Test nekalosti správania sa podnikatelov k spotrebitelom v slovenskom práve. In: G. Urbanská (ed.): Ingerencia súdov do súkromnoprávnych zmlúv: Zásahy súdov do kontraktačného procesu. Justičná akadémia SR, Pezinok, 2013, 144-145. 
számú, 2012. április 26-i határozata a fogyasztó vételár tekintetében fennálló érdekeltségét emelte ki, és hangsúlyozta, hogy nem minden fogyasztó vásárol árukat részletre, egyúttal nem is rendelkezik mindenki tapasztalattal az ilyen típusú értékesítés kapcsán.

A2015. november 18-i határozatában (PLz. ÚS 5/2015), azAlkotmánybíróság megállapította, hogy a fogyasztókat kiszolgáltatott személyeknek kell tekinteni. ${ }^{5}$ Ennek megfelelően, következetesen kiszolgáltatott személyként azonosítja a fogyasztókat. A bíróságok különös figyelmet fordítanak a fogyasztók helyzetére (szegények, eladósodottak), mivel személyes helyzetük fontos tényező az ügyletre vonatkozó döntésük meghozatalában. A Pozsonyi IV. kerületi Bíróság a 2014. szeptember 3-án hozott, 5C/64/2009. sz. ítéletében megállapította, hogy az alperes nyugdíjas voltára tekintettel kiszolgáltatottnak tekintendő (a tisztességtelen kereskedelmi gyakorlatot illetően, amikor valótlanul állítják, hogy egy termék képes gyógyítani egy betegséget).

A Popradi Kerületi Bíróság 2011. december 20-i 17C/113/2010. sz. ítéletében kimondta, hogy az internet átlagos fogyasztója ma már nem különbözik lényegesen az áruházakat, üzleteket ténylegesen (és nem virtuálisan) látogató átlagos fogyasztóktól. A bíróság döntésében utalt az internet széles körű használatára a Szlovák Köztársaságban, és arra a tényre, hogy a sok fogyasztó külön erre vonatkozó oktatás nélkül használja az online vásárlást és az online szolgáltatásokat.

A Szlovák Nemzeti Bank gyakorlata szintén az átlagfogyasztó fogalmára összpontosít a tisztességtelen kereskedelmi gyakorlatok vonatkozásában. A bank a 2019. december 23-án kelt NBS1-000-037-987. számú határozatában foglalkozik az uniós jognak megfelelö értelmezés kérdésével (a 2005/29/ EK irányelv 18. és 19. preambulum-bekezdése, az Európai Unió Bíróságának a C-435/11. sz. CHS Tour ítélete, ${ }^{6}$ valamint a Bizottság SWD (2016) 163. számú szolgálati munkadokumentuma ${ }^{7}$ alapján). Ebben a határozatban a Szlovák Nemzeti Bank kimondta, hogy az „átlagos fogyasztó” fogalma elvont fogalom, értelmezése pedig jogkérdés. Azt is kijelentette, hogy az átlagfogyasztótól nem várható el az adó- és kártérítési felelősségi (jog)szabályok mélyebb ismerete.

5 Lásd még ehhez a Nitrai (Nyitrai) Járásbíróság 2014. április 1-jei, 15C/55/2013. számú ítéletét.

6 C-435/11. sz. CHS Tour Services GmbH kontra Team4 Travel GmbH ügyben 2013. szeptember 19-én hozott ítélet, ECLI:EU:C:2013:574

7 A Bizottság SWD (2016) 163. számú szolgálati munkadokumentuma a tisztességtelen kereskedelmi gyakorlatokról szóló 2005/29/EK irányelv végrehajtásához és alkalmazásához. 


\section{TisZTESSÉGTELEN KERESKEDELMI GYAKORLATOK - SZLOVÁKIA}

\section{Jogérvényesítési lehetőségek a tisztességtelen kereskedelmi gyakorlatokkal szemben - igazgatási, polgári és büntetőjogi eszközök}

A szlovák jog szerint két fó módszer van a tisztességtelen kereskedelmi gyakorlatokkal szembeni fellépésre. A tisztességtelen kereskedelmi gyakorlatokra vonatkozó rendelkezések végrehajtása és betartatása közigazgatási hatósági és bírósági hatáskörébe tartozik, a védelmi módok jellege és célja azonban eltérő.

A fogyasztók jogaikat közvetlenül a bíróságok előtt is érvényesíthetik. A szlovák jog nem követeli meg előzetesen a közigazgatási szerv előtti eljárást vagy a bírósági eljárás előtti kötelező alternatív vitarendezési eljárást a tisztességtelen kereskedelmi gyakorlatról szóló rendelkezések szerinti igény érvényesítése érdekében. A polgári perben a bíróságok magánjogi vitákat kísérelnek meg rendezni. Más szóval, a polgári peres eljárás lényege egy adott fogyasztó és egy adott vállalkozás közötti jogvita rendezése, valamint annak mérlegelése, hogy a felperes követelése megalapozott-e.

Ami a közigazgatási hatóságokat illeti, a hatáskörükbe tartozó eljárások célja a tisztességtelen kereskedelmi gyakorlatot vagy gyakorlatokat folytató vállalkozások szankcionálása, általában pénzbírság kiszabásával. A hatóságok jogköre kiterjed a vállalkozás által folytatott tisztességtelen kereskedelmi gyakorlat betiltására is. A különféle közigazgatási szervek hatásköreinek megoszlása absztrakt természetű kérdés. Ezért, az igazgatási hatóságok nem döntenek a fogyasztó és a vállalkozás közötti konkrét jogviszonyról. A hatóság azt méri fel, hogy a vállalkozás általában tisztességtelen kereskedelmi gyakorlatokat alkalmaz-e (meghatározhatatlan számú fogyasztóval szemben). A cél a fogyasztók kollektív érdekeinek védelme (absztrakt vizsgálat).

Fontos megemlíteni, hogy a polgári bíróságok is rendelkeznek bizonyos hatáskörrel a fogyasztók kollektív érdekeinek védelmében. A közigazgatási hatóságok és a bíróságok közötti hatásköri elhatárolás ebben az értelemben nem teljesen világos.

A 2005/29/EK irányelv alapján átültetett rendelkezésekkel biztosított jogok érvényesülését a büntetőjog is védi. A szlovák büntető törvénykönyv (Tt. 300/2005 sz. törvény) szabályozza a fogyasztókkal szembeni tisztességtelen kereskedelmi gyakorlatok elnevezésü büncselekményt. A Szlovák Büntető Törvénykönyv 269a. \$-ának (1) bekezdése szerint, aki a fogyasztó jogait olyan kereskedelmi gyakorlaton alapuló magatartással sérti meg, amely 
minden körülmények között tisztességtelennek minősül a fogyasztóvédelemre vonatkozó különös szabályok alapján,

a) ha az elkövetést megelőző 24 hónapban korábban ugyanilyen cselekmény miatt elítélték, vagy az ugyanilyen büncselekmény miatt kiszabott szabadságvesztéséből szabadult,

b) ha az elkövetést megelöző 24 hónapban hasonló cselekmény miatt elítélték, hat hónaptól három évig terjedő szabadságvesztéssel büntetendő.

\section{A tisztességtelen kereskedelmi gyakorlat hatása a fogyasztói szerződésekre}

A Szlovák Köztársaságban nincs egyértelmű (explicit) jogi rendelkezés, amely alkalmazható lenne a szerződésből származó olyan igényekre, amelyek a vállalkozás által alkalmazott tisztességtelen kereskedelmi gyakorlatokból erednek (felelősség az okozott kárért, a megállapodás szerinti ár csökkentése stb.), a tisztességtelen kereskedelmi gyakorlatok azonban hatással lehetnek a szerződéses kapcsolatokra.

A tisztességtelen kereskedelmi gyakorlatok befolyásolhatják a jognyilatkozatok érvényességét is. A szlovák Polgári Törvénykönyv (Tt. 40/1964. számú törvény, továbbiakban SzPtk.) 53d. \$-a szerint: „Az a fogyasztói szerződés, amely bíróság határozatának megállapításai alapján tisztességtelen szerződési feltételt tartalmaz, és amelynek megkötését tisztességtelen kereskedelmi gyakorlat vagy uzsora alkalmazásával érték el, érvénytelen.”

Az SzPtk. említett 53d. \$-ának alkalmazása nem gyakori. A rendelkezés ugyanis két feltétel együttes teljesülése esetén alkalmazható. Az első feltétel teljesítése, amely szerint a fogyasztói szerződésnek legalább egy tisztességtelen feltételt kell tartalmaznia, problematikus. Ehhez ugyanis a feltételta bíróságkorábbi határozata kell, hogy tisztességtelennek nyilvánítsa más (korábbi) eljárás során. Ilyen értelemben a fent említett rendelkezés kapcsolódik az SzPtk. 53a. \$-ához, amely szerint, ha a bíróság egy olyan fogyasztói szerződés valamelyik szerződési feltételét, melyet több esetben is megkötnek, és melyek esetében megszokott, hogy a fogyasztó a szerződés tartalmát jelentős módon nem befolyásolja, annak tisztességtelen volta miatt érvénytelennek nyilvánította, illetve nem ismerte el a vállalkozás teljesítését egy ilyen feltétel miatt, a vállalkozás köteles az ilyen feltétel vagy ugyanilyen értelmű feltétel alkalmazásától tartózkodni valamennyi, 


\section{TisZTESSÉGTELEN KERESKEDELMI GYAKORLATOK - SZLOVÁKIA}

fogyasztókkal kötött szerződésben. ${ }^{8}$ E rendelkezéssel kapcsolatos aggály, hogy a Szlovák Köztársaságnak nincs nyilvánosan hozzáférhető listája a bíróságok által tisztességtelennek nyilvánított fogyasztói szerződési feltételekről.

Azaz eset is előfordulhat, hogy a fogyasztónak egy elözetes bírósági eljárásban keresetet kell benyújtania a tisztességtelen szerződési feltétel vagy feltételek megállapítása céljából, annak érdekében, hogy megalapozottan kérhesse egy szerződés érvénytelenné nyilvánítását az SzPtk. említett $53 \mathrm{~d}$. \$-a szerinti másik polgári per során. Ez meglehetősen megnehezíti a fogyasztó helyzetét, ugyanis az egyik polgári eljárásban a szerződési feltétel (feltételek) tisztességtelenségének megállapítását kell kérnie, ${ }^{9}$ a másik polgári eljárásban pedig a szerződés érvénytelenségének megállapítása, és az ebből eredő jogkövetkezmények iránt indíthat pert (jogalap nélküli gazdagodás).

Ezenkívül, a tisztességtelen szerződési feltétel alkalmazása miatt szóba jöhet a fogyasztói szerződés érvénytelensége az SzPtk. általános szabálya, a 49a. \$-a alapján, mivel a jognyilatkozat érvénytelen, ha annak megkötésekor a fél valamely lényeges körülmény tekintetében tévedésben volt, feltéve, ha tévedését a másik fél okozta vagy felismerhette. A jognyilatkozat akkor is érvénytelen, ha a tévedést a másik fél szándékosan okozta.

Agresszív kereskedelmi gyakorlat esetén a fogyasztói szerződést érvénytelennek lehet tekinteni különösen a fogyasztónak jognyilatkozat megkötésére irányuló szabad akaratának hiánya miatt. Az SzPtk. 37. \$ (1) bekezdésének értelmében a jognyilatkozatot szabad akaratelhatározásból kell megtenni, ellenkező esetben az érvénytelen.

A tisztességtelen kereskedelmi gyakorlatok általában olyan magatartást (vagy mulasztást) képviselnek, amelyek ellentétesek a jó erkölccsel (bonos mores). Jó erkölcsbe ütközik az SzFvt. 4. \$ (8) bekezdése (kizárólag a törvény alkalmazásában)

8 A szlovák Polgári Perrendtartás (Tt. 160/2015. sz. törvény) 298. $\$(2)$ bekezdése szerint, ha a bíróság megállapítja valamely szerződési feltétel érvénytelenségét annak tisztességtelensége okán, akkor a bíróság kifejezetten és pontosan megjelöli ezt a tisztességtelen szerződési feltételt az ítélet rendelkező részében.

9 Lehetséges a tisztességtelen szerződési feltétel megállapítását kérni konkrét fogyasztói szerződésben is a jogkövetkezmények iránti igény érvényesítése nélkül (Szlovák Legfelsőbb Bíróság 2019. március 28-i 6 Cdo. 27/2018. számú döntése). Mészáros egyetért ezzel a döntéssel. Lásd: P. Mészáros: Uznesenie Najvyššieho súdu SR sp. zn. 6 Cdo 27/2018 z 28.3.2019 (charakter žaloby o posúdenie neprijatelnosti podmienky v spotrebitel'ských zmluvách). Súkromné právo, 2019/3. Az igény érvényesítésének eljárási szabályai azonban eltérnek az általános szabálytól. A Polgári Perrendtartás 137 . \$-a szerint, amely az igény érvényesítését szabályozza, az igényérvényesítés célja nem lehet megállapítás, ha egyúttal a jogviszony vagy egyéb körülmény alapján a jogkövetkezmények iránt is igényt lehet előterjeszteni. Tisztességtelen szerződési feltétel esetén ez az elv nem alkalmazandó, a fogyasztók védelme és a bíróság előtti fogyasztói igények érvényesítésének hatékony biztosítása miatt. 
szerint minden olyan magatartás, amely ellentétes a társadalmi hagyományokkal, ami magában foglalja a nyilvánvalóan hátrányos megkülönböztetés elemeit, eltér azoktól az erkölcsi szabályoktól, amelyek az adott termék vagy szolgáltatás nyújtására vonatkoznak, vagy amely magatartás a jóhiszeműség, a tisztesség, vagy a szokásos gyakorlat megsértésével vagy felhasználásával, illetőleg kihasználásával tévedésbe ejtő, megtévesztő, fenyegetést valósít meg, vagy a felek jelentős egyenlőtlenségét és a szerződéses szabadság megsértését eredményezheti. A tisztességtelen kereskedelmi gyakorlat alkalmazása indok lehet az SzPtk. 3. $\$(1)$ bekezdésének alkalmazására is, amelynek értelmében a polgári jogi jogviszonyokból eredő jogok gyakorlása és kötelezettségek teljesítése alapos ok nélkül nem érintheti mások jogait és jogos érdekeit, és nem lehet ellentmondásban a jó erkölccsel.

Eltekintve a szerződés érvénytelenségétől, tisztességtelen kereskedelmi gyakorlat alkalmazása esetén az SzPtk. 49. \$-a is lehetőséget biztosít az elállásra, amely szerint a fél, aki a szerződést kiszolgáltatott helyzetben, feltűnően előnytelen feltételek mellett kötötte meg, jogosult a szerződéstől való elállásra.

Meg kell említeni a tisztességtelen kereskedelmi gyakorlat alkalmazását a különböző értékesítési akciókkal összefüggésben (előadások, hirdetési rendezvények a közösség számára hozzáférhető nyilvános helyeken). Az ilyen típusú tisztességtelen kereskedelmi gyakorlat olyan gyakori volt, hogy a Szlovák Köztársaságnak különleges igazgatási jellegű szabályokat kellett bevezetnie az ilyen tevékenységekre. A termékek és szolgáltatások távollevők közötti és üzlethelyiségen kívüli értékesítéséről szóló törvény (Tt. 102/2014.) 11. \$-a szerint, ha a vállalkozás értékesítési akciót szervez, köteles azt előzetesen bejelenteni a Szlovák Kereskedelmi Felügyeletnek, különösen a meghívó és a szerződési feltételek megküldésével, valamint az értékesítésre kínált termékek listájával és a kínálati árakkal. E kötelezettség megszegése a vállalkozásra súlyos következményekkel járhat, különösen, hogy a megkötött fogyasztói szerződést nemlétezőnek kell tekinteni.

Budjač szerint a tisztességtelen kereskedelmi gyakorlatok potenciális forrásai a tisztességtelen szerződési feltételeknek, egyúttal felgyorsítják azok állandósult alkalmazását. ${ }^{10} \mathrm{Az}$ SzPtk. 53. $\$(12)$ bekezdése értelmében: „A tisztességtelen szerződési feltételeket az áruk vagy szolgáltatások jellegére tekintettel, valamint a szerződés megkötésének időpontjában a szerződéskötés szempontjából lényeges

10 M. Budjač: 53. \$. In: M. Števček et al. (eds.): Občiansky zákonník I. $\$ 1-450$. Komentár. C. H. Beck, Prague, 2015, 662. 


\section{TisZTESSÉGTELEN KERESKEDELMI GYAKORLATOK - SZLOVÁKIA}

körülmények és feltételek alapján kell értékelni. Ezzel összefüggésben Budjač szerint, ha a bíróság szerződési feltételek tisztességtelenségét vizsgálja, ez egyúttal azt is jelenti, hogy a bíróság burkoltan a tisztességtelen kereskedelmi gyakorlatokat is figyelembe veszi. ${ }^{11}$

\section{Bírósági jogvédelem}

\subsection{Bírósághoz fordulás lehetősége egyéni jogvitákban}

Azokban az esetekben, ahol a tisztességtelen kereskedelmi gyakorlat a fogyasztói szerződés érvénytelenségét eredményezi (ezért a vállalkozás részéről a jogalap nélküli gazdagodás lehetősége jön számításba) vagy egyéb jogkövetkezményekhez vezet (például a szerződéstől való elállás jogának gyakorlásához), elvárt, hogy a fogyasztót megillethesse a bírói jogvédelem, különösen, ha ez nem kisértékű követelést foglal magába.

Az SzFvt. 3. \$ (5) bekezdése szerint, ha a fogyasztó jogainak sérelmét a bíróság megállapította, a fogyasztó a vállalkozással szemben az őt ért sérelemért - beleértve a nem vagyoni sérelmet is - kártérítést is követelhet.

A Tt. 71/1992 sz. törvény 4 . $\$$ (2) bekezdés v) pontja szerint a fogyasztók a fogyasztói jogvitákban mentesülnek a bírósági illetékek megfizetése alól, függetlenül attól, hogy a perben felperesként vagy alperesként vesznek részt. Ugyanakkor az eljárási költségeket a vesztes fél köteles viselni. A fogyasztóknak tudatában kell lenniük azon kockázatnak, hogy ha jogaikat nem sikerül érvényesíteniük a bírósági eljárásban, akkor a bírósági eljárás és a pernyertes fél költségeinek megtérítésére kötelezhetők. Ezen túlmenően, a jogi tanácsadás általában költségekkel jár. $\mathrm{Ha}$ a fogyasztó rászorul, akkor a Központi Jogsegélyszolgálat által nyújtott ingyenes jogsegélyre lesz jogosult.

A kártérítési felelősséggel összefüggő jogi szabályozás, azaz a szlovák Polgári Perrendtartásról szóló törvény (SzPp.), speciális rendelkezéseket tartalmaz a fogyasztói vitákra, előnyben részesítve a gyengébbik felet (a bizonyítással, a bíróság kioktatási kötelezettségével kapcsolatban stb.) Az SzPp. 6. \$ (1) bekezdése kifejezetten is foglalkozik a fogyasztók védelmének elvével (eljárásjogi értelmében).

11 M. Budjač: Nekalé obchodné praktiky ako potenciálny zdroj a akcelerátor sústavného používania neprijatelných zmluvných podmienok a ich vplyv na platnost spotrebitel'skej zmluvy. In: G. Urbanská (ed.): Ingerencia súdov do súkromnoprávnych zmlúv: Zásahy súdov do kontraktačného procesu. Justičná akadémia SR, Pezinok, 2013, 121. Lásd még:R. Dobrovodský: i. m., 127. 
Mindezektől függetlenül, az elhúzódó polgári peres eljárások nagyban megnehezítik a hatékony(abb) bíróság előtti fogyasztói jogérvényesítést. Ezen kívül, a kisértékű fogyasztói igények érvényesítése gyakran nem áll arányban a pereskedésre fordított idővel és költségekkel.

\subsection{Bírósághoz fordulás absztrakt vizsgálat lefolytatása érdekében}

Az SzFvt. 3. \$ (5) bekezdése szerint a fogyasztóvédelmi szervezet fogyasztók kollektív érdekeit sértő jogellenes cselekmény esetén kérheti a bíróságtól, hogy kötelezze a jogsértő vállalkozást a jogellenes cselekménytől való tartózkodásra. E rendelkezés alkalmazása nem korlátozódik a fogyasztóvédelmi (jog)területre vagy egyes irányelvekre.

A korábban említett értelemben a szlovák Polgári Perrendtartás szabályoz speciális, fogyasztóvédelmi tárgyú eljárásokat is: a fogyasztói szerződésekben megvalósuló tisztességtelen szerződési feltételek és a tisztességtelen kereskedelmi gyakorlat absztrakt vizsgálatát (301-306. \$-ok). A jogszabály lehetőséget biztosít peres eljárás megindítására vállalkozással szemben a tisztességtelen kereskedelmi gyakorlat absztrakt vizsgálata érdekében, egyedi jogvita kezdeményezése nélkül. Az ilyen típusú eljárások célja a fogyasztók kollektív érdekeinek védelme az egyedi eset körülményeitől függetlenül.

A fenti eljárásokban a fogyasztóvédelmi szervezetek és a nemzeti végrehajtó hatóságok (például Szlovák Kereskedelmi Felügyelet vagy a Szlovák Nemzeti Bank a pénzügyi szektor fogyasztóinak védelme érdekében) nyújthatnak be keresetet a vállalkozásokkal szemben. Azaz, a tisztességtelen kereskedelmi gyakorlat absztrakt vizsgálata nem kezdeményezhető a fogyasztó által. ${ }^{12}$ A fogyasztók ezen eljárásoknak nem résztvevői, peres félként a fogyasztóvédelmi szervezet (vagy más illetékes hatóság) és a vállalkozás szerepel az eljárásban.

A magasabb szintű jogbiztonság elősegítése érdekében, tekintettel a fogyasztói ügyekben lefolytatott absztrakt vizsgálat nehézségeire, első fokon a regionális bíróságok járnak el (és nem a járásbíróságok). Konkrétan, a Szlovák Köztársaságban működő nyolc regionális bíróságból csak háromnak van hatásköre ezekben az ügyekben eljárni (Pozsonyi Regionális Bíróság, Besztercebányai Regionális Bíróság, Kassai Regionális Bíróság). A szlovák Legfelsőbb Bíróság mint másodfokú bíróság jár el ezekben az esetekben. Bár az említett eljárásban

12 Lásd a Szlovák Köztársaság Legfelsőbb Bíróságának 2017. július 26-i, 7 Ndc 9/2017. számú ítéletét. 


\section{TisZTESSÉGTELEN KERESKEDELMI GYAKORLATOK - SZLOVÁKIA}

a fogyasztó nem peres fél, az SzPp. a felperesekre (a fogyasztóvédelmi szervezetekre, illetve a nemzeti ellenőrző hatóságokra) kedvezőbb szabályokat állapít meg, hasonlóan a fogyasztók egyéni jogvitáiban érvényesülő szabályokhoz.

Ha a bíróság eljárása eredményes, döntésében megállapítja a tisztességtelen kereskedelmi gyakorlatot, és egyúttal megtiltja annak további alkalmazását. Amint azt a Pozsonyi Regionális Bíróság 2019. január 31-i 14C/4/2016. sz. döntésében kimondta, az eljárás nem lehet eredményes, ha a kereskedelmi gyakorlat megismétlődésének veszélye a jövőben nem valószínű (vagy nem fenyeget).

Az SzPp. 306. \$-a szerint az absztrakt vizsgálattal összefüggő, jogerőre emelkedett döntések mindenkivel szemben hatályosak. E rendelkezés gyakorlati alkalmazása azonban nem tisztázott. ${ }^{13} \mathrm{~A}$ rendelkezés szó szerinti értelmezése esetén arra a következtetésre juthatunk, hogy az ítélet minden, azonos tartalmú gyakorlatot alkalmazó vállalkozással szemben végrehajtható volna, holott az ilyen értelmezés rendkívül aggályos, egyúttal sérti a többi (az absztrakt vizsgálattal nem érintett) vállalkozás tisztességes eljáráshoz való jogát.

A gyakorlatban ezt az eljárást nem alkalmazzák széles körben. A fogyasztói ügyek absztrakt vizsgálata a Szlovák Köztársaságban ténylegesen elsősorban a közigazgatási jogban működik.

Fontos megemlíteni, hogy a bíróság előtti, tisztességtelen szerződési feltételek és tisztességtelen kereskedelmi gyakorlat miatti absztrakt vizsgálati eljárás keretében a szlovák Polgári Perrendtartás nem teszi lehetővé kártérítés, jogalap nélküli gazdagodás vagy pénzügyi jóvátétel követelését a fogyasztók számára. Ez az eljárás jövőbeni magatartásokra irányul, ezért elsősorban preventív hatása van. ${ }^{14}$ A Szlovák Köztársaságban a károsult fogyasztók kárának tömeges megtérítésére nincs jogi lehetőség (fogyasztók kollektív érdekeinek érvényesítése esetén). Az anyagi jóvátételt is magában foglaló kollektív fellépés lehetősége terra incognita a Szlovák Köztársaságban. A szlovák jogrendszer nem ismeri el a fogyasztóvédelmi szervezetek (vagy a fogyasztóvédelmi ügyben hatáskörrel rendelkező hatóságok) jogát arra, hogy a fogyasztók kollektív érdekeinek megsértése esetén kártérítési igénnyel léphessenek fel.

13 Lásd M. Maslák: Úskalia erga omnes účinkov rozsudku v konaní o abstraktnej kontrole v spotrebitel'ských veciach. Súkromné právo. Vol. 3, 2017/3. 111.

14 Lásd M. Maslák: i. m., 2017, 106. Lásd még D. Zavadová: Konanie o abstraktnej kontrole v spotrebitel’ských veciach. Súkromné právo, 2017/1. 22-28. 


\section{Közigazgatási jogvédelem}

\section{1. Általános hatásköri szabályok}

A tisztesség telen kereskedelmi gyakorlatok elleni fellépés a bírósági jogérvényesítés mellett a közigazgatási szerveken keresztül lehetséges. Az SzFvt. 20. \$ (1) bekezdése szerint a Szlovák Kereskedelmi Felügyelet az az általános felügyeleti hatóság, amely felhatalmazással rendelkezik a törvényben elöírt kötelezettségek betartásának felügyeletére és ellenőrzésére. ${ }^{15}$ Más szóval, a Szlovák Kereskedelmi Felügyelet mögöttes hatáskörrel rendelkezik. Külön törvények értelmében más közigazgatási hatóságok is rendelkeznek hatáskörrel egyes területeken a fogyasztóvédelmi szabályok betartásának ellenőrzésére. A pénzügyi szektorban (a pénzügyi szektor fogyasztóinak védelme érdekében) a Szlovák Nemzeti Bank ${ }^{16}$ gyakorolja ezt a hatáskört, az energetikai ágazatban a Hálózatos Iparágak Szabályozó Irodája, ${ }^{17}$ a távközlési és a postai szolgáltatások területén pedig az Elektronikus Kommunikáció és a Postai Szolgáltatások Szabályozó Hatósága. ${ }^{18}$

Erős kompetenciákról beszélhetünk a tisztességtelen kereskedelmi gyakorlatok elleni végrehajtás terén a Szlovák Kereskedelmi Felügyelet és a Szlovák Nemzeti Bank esetében.

Ami a Hálózatos Iparágak Szabályozási Irodáját illeti, noha az energetikai ágazat ezen hatóságának felhatalmazása van az egyetemes szolgáltatók szerződéses feltételeinek jóváhagyására a gáz- és villamosenergia-ellátás területén, a Szlovák Kereskedelmi Felügyelet jogosult a tisztességtelen szerződési feltételekkel és a tisztességtelen kereskedelmi gyakorlatokkal szembeni fellépésre. Ezen kívül a fogyasztói jogok ellenőrzése tekintetében a Szlovák Kereskedelmi Felügyelet és az Elektronikus Hírközlési és Postai Szolgáltatások Szabályozó Hatósága közötti hatáskörmegosztás sem egyértelmü.

\subsection{A Szlovák Kereskedelmi Felügyelet eljárása}

Az SzFvt. 24. \$-a értelmében a törvényben megállapított kötelezettségek megszegése esetén a felügyeleti hatóság 66400 euróig, a jogsértés 12 hónapon

15 Angol nyelvü honlap elérhető itt: https://www.soi.sk/en/SOI.soi

16 Angol nyelvü honlap elérhetö itt: https://www.nbs.sk/en/consumer

17 Angol nyelvü honlap elérhető itt: http://www.urso.gov.skl?language=en

18 Angol nyelvü honlap elérhető itt: https://www.teleoff.gov.sk/regulatory-authority-for-electronic-communicationsand-postal-services/ 


\section{TisZTESSÉGTELEN KERESKEDELMI GYAKORLATOK - SZLOVÁKIA}

belüli megismétlődése esetén pedig 166000 euróig terjedő bírságot szab ki a vállalkozással szemben (általános szabály). A hivatkozott törvény 24 . $\$$ (5) bekezdése szerint a bírság összegének meghatározásakor figyelembe kell venni a jogsértő cselekmény jellegét, a kötelezettségszegés súlyát, valamint a jogsértés módját és következményeit. A bírság attól a naptól számított egy éven belül szabható ki, amikor a felügyeleti hatóság tudomást szerzett az SzFvt. szerinti kötelezettség megszegéséről, de legkésőbb a jogsértés elkövetésének napjától számított három éven belül. A bírság kiszabását a közigazgatási hatóság hivatalból (ex officio) kezdeményezi, azonban a fogyasztói panaszok vagy a fogyasztóvédelmi szervezetek javaslatai nagy segítségül szolgálnak a közigazgatási szerv számára.

A Szlovák Kereskedelmi Felügyelet hatásköreit a Tt. 128/2002. számú, a belső piac fogyasztók ügyeit érintő állami ellenőrzéséről szóló törvény szabályozza. E törvény 10. $\$(4)$ bekezdése értelmében a Szlovák Kereskedelmi Felügyelet együttműködik a fogyasztóvédelmi szervezetekkel, panaszaikat és értesítéseiket az eljárása során felhasználja.

A pénzbírság kiszabása mellett az SzFvt. elismeri a hatóság más hatáskörét is. Ha a vállalkozás a fogyasztók kollektív érdekeit sérti, az SzFvt. 21. \$-a alapján a fogyasztóvédelmi szervezet javaslatot tehet a Szlovák Kereskedelmi Felügyeletnek ideiglenes intézkedés elrendelésére. Ilyen ideiglenes intézkedést a hatóság hivatalból is elrendelhet. A fogyasztóvédelmi szervezeteknek a javaslatukban bizonyítaniuk kell, hogy a vállalkozás a fogyasztói szervezet írásbeli felszólításának kézhez vételétől számított két héten belül sem tartózkodott a fogyasztók kollektív érdekeit sértő cselekménytől (például tisztességtelen kereskedelmi gyakorlatot alkalmazott). ${ }^{19}$

Az ilyen ideiglenes intézkedések széles körben elterjedtek, és hatékonyan akadályozzák meg a fogyasztók kollektív érdekeinek nyilvánvaló megsértését. Az SzFvt. nem ír elő határidőt, amelyen belül a hatóság köteles volna dönteni a fogyasztóvédelmi szervezet intézkedés elrendelésére irányuló javaslatáról. Az említett jogintézmény jellege azonban azt sugallja, hogy az intézkedést a lehető leghamarabb meg kell hozni. Az SzFvt. 21. \$(3) bekezdése szerint a vállalkozás az ideiglenes intézkedés ellen három napon belül írásbeli kifogást nyújthat be, de a kifogásnak az intézkedés végrehajtására nincs halasztó hatálya. Az ideiglenes intézkedést kibocsátó felügyeleti hatóság felettes hatósága a kifogással kapcsolatos döntését annak kézhezvételétől számított öt napon belül hozza meg.

19 SzFvt. 21. \$ (1) bekezdés. 
E tekintetben helyénvaló megemlíteni a Szlovák Kereskedelmi Felügyelet által a viszonylag jól ismert utazási irodával, a CK Hechter Slovakia, spol. s. r. o-val szemben alkalmazott ideiglenes intézkedést. ${ }^{20} \mathrm{~A}$ Szlovák Kereskedelmi Felügyelet elrendelte a csomagban értékesített utazási szerződések megkötésének, mint tisztességtelen kereskedelmi gyakorlat alkalmazásának a megszüntetését, mivel az utazási iroda nem rendelkezett kötelező biztosítással vagy bankgaranciával csőd esetére. A vállalkozás az ideiglenes intézkedés után folytatta az említett tisztességtelen kereskedelmi gyakorlat alkalmazását, ${ }^{21}$ ezt követően a hatóság 66000 euró bírságot szabott ki vele szemben, amely a médiában is nyilvánosságot kapott. ${ }^{22}$ Említésre méltó egy másik ideiglenes intézkedés is, amelyet a Szlovák Kereskedelmi Felügyelet rendelt el egy olyan vállalkozással szemben, amely a fogyasztóknak küldött felszólításában a fogyasztó vagyonára vezetendő végrehajtással fenyegetőzött (úgy, hogy nem volt végrehajtási jogcíme). ${ }^{23}$

A Szlovák Kereskedelmi Felügyelet másik eszköze a fogyasztók részére történő termékértékesítés vagy a szolgáltatás nyújtás legfeljebb három évig terjedő megtiltása, ha a vállalkozás a fogyasztók kollektív érdekeit sértő cselekményét követő 12 hónapon belül a fogyasztók kollektív érdekeit ismételten megsérti [SzFvt. 20a. $\$(2)$ bekezdés].

Amint azt a Szlovák Kereskedelmi Felügyelet 2019. évi éves jelentése megállapítja, a tisztességtelen kereskedelmi gyakorlatok ellenőrzése a fogyasztóvédelmi ellenőrzés egyik legfontosabb területe. ${ }^{24}$ 2019-ben a Szlovák Kereskedelmi Felügyelet 305 esetben állapította meg, hogy a vállalkozások tisztességtelen kereskedelmi gyakorlatokat alkalmaznak (ez 47 esettel kevesebb, mint 2018-ban). ${ }^{25}$

Mindemellett megjegyzendő, hogy a Szlovák Kereskedelmi Felügyelet nem rendelkezik elegendő létszámú alkalmazottal ahhoz, hogy a fogyasztóvédelem területén érvényesülő széleskörű hatáskörét kielégítően ellássa. ${ }^{26}$

20 A Szlovák Kereskedelmi Felügyelet 2016. július 22-i, 2069/04/2016. számú ideiglenes intézkedése.

21 Annual report of the Slovak Trade Inspection, 2016, 42. Elérhető: https://www.soi.sk/sk/Kontrolna-cinnost/ Vyrocne-spravy.soi (letöltés dátuma: 2020.03.10.)

22 Elérhető: https://www.noviny.sk/slovensko/173558-hechter-musi-zaplatit-pokutu-66-000-eur (letöltés dátuma: 2020.03.10.)

23 Elérhető: https://www.sospotrebitelov.sk/sos/soi-firma-vymahala-pohladavky-vyhraznymi-sms-spravami/ (letöltés dátuma: 2020.03.10.)

24 Annual report of the Slovak Trade Inspection, 2019, 5. Elérhető: https://www.soi.sk/sk/Kontrolna-cinnost/ Vyrocne-spravy.soi (letöltés dátuma: 2020.03.10.)

25 Annual report of the Slovak Trade Inspection, 2019, i. m. 33.

26 Ez a Szlovák Kereskedelmi Felügyelet éves jelentésében (Annual report of the Slovak Trade Inspection, 2019, i. m.) is megállapításra került. 


\section{TisZTESSÉGTELEN KERESKEDELMI GYAKORLATOK - SZLOVÁKIA}

\subsection{A Szlovák Nemzeti Bank eljárása}

A pénzügyi szektor fogyasztóinak védelméért felelős felügyeleti hatóság a Szlovák Nemzeti Bank. A pénzügyi fogyasztók közigazgatási jogi védelmét Tt. 747/2004. számú, a pénzügyi piac felügyeletéről szóló törvény szabályozza.

E törvény 35f. \$-a értelmében a Szlovák Nemzeti Bank 1000000 euróig, 12 hónapon belüli ismételt jogsértés esetén 2000000 euróig terjedő pénzbírságot szab ki. A bírságot a megállapított jogsértés súlyának, terjedelmének, időtartamának, következményeinek és jellegének megfelelően kell kiszabni.

A Tt. 747/2004. számú, a pénzügyi piac felügyeletéről szóló törvény (Ppftv.) 35e. $\$(3)$ bekezdése szerint, ha a Szlovák Nemzeti Bank részéről felmerül a gyanú, hogy az általa felügyelt szervezet olyan módon sértette a fogyasztói jogokat, hogy az a pénzügyi piac fogyasztóinak a kollektív érdekeit sérti, ideiglenes intézkedést hozhat a felügyelt szervezettel szemben, amelyben kötelezi a jogsértéstől való tartózkodásra. A pénzügyi szektorban a fogyasztók védelme érdekében a Szlovák Nemzeti Bank mint nemzeti hatóság, ilyen intézkedéseket hoz. A hatóság a 2019. május 30-i, NBS1-000-037-870. számú határozatában megtiltotta a tisztességtelen kereskedelmi gyakorlat alkalmazását, amely abban állt, hogy a vállalkozás jogszabályváltozásra hivatkozva (speciális, biztosításokat terhelő adó kivetése) közleményében megemelte a biztosítási díjakat, anélkül, hogy a biztosítási díjakat egyoldalúan érvényesen megváltoztat(hat)ta volna, vagy a fogyasztóval a biztosítási díjak megemeléséről külön megállapodásban rendelkeztek volna.

Ezenkívül a Ppftv. 35e. \$-ában és a 35f. \$ (1) bekezdésének c) pontjában kifejezetten elöírja, hogy a Szlovák Nemzeti Bank határozatában az általa felügyelt szervezet számára megtilthatja a tisztességtelen kereskedelmi gyakorlatok alkalmazását.

A pénzügyi fogyasztóvédelem terén fennálló hiányosságok miatt a Szlovák Nemzeti Bank visszavonhatja a felügyelt szervezet működési engedélyét vagy más, a pénzügyi piaccal kapcsolatos tevékenységre vonatkozó engedélyét (Ppftv. 35g. $\$$ (1) bekezdés).

A szankciók célja a pénzügyi piac fogyasztói védelmének a biztosítása. ${ }^{27}$ A Szlovák Nemzeti Bank jelentősnek mondható hatáskörrel rendelkezik. Egyúttal viszonylag szűk szakterületen tevékenykedik, és szakmailag is jól felkészült.

27 Lásd még A. Slezáková, P. Mikloš: Zákon o dohlade nad finančným trhom - komentár. Wolters Kluwer, Bratislava, 2018. , a Ppftv. 35f. \$-ához füzött kommentár. 
A gyakorlatban a Szlovák Nemzeti Bank tevékenysége pozitív tapasztalatokkal szolgál. A Szlovák Nemzeti Bank 2018-ban összesen 1948 beadványt kapott a pénzügyi piac fogyasztóitól. ${ }^{28}$ A fogyasztói beadványok információforrásként szolgáltak, amelyeket a Szlovák Nemzeti Bank a pénzügyi fogyasztók védelmével kapcsolatos hatáskörének gyakorlása (ellenőrzése) során felhasznált.

A Szlovák Köztársaságban általában hatékonyak a fogyasztói jogok védelmének hatósági eszközei. A döntéshozatali tevékenységet illetően, különösen a Szlovák Nemzeti Bank esetében, a döntések részletes indokolása ugyancsak kiemelendő.

\subsection{A közigazgatási bírság megállapításának szempontjai}

Amint azt a Szlovák Köztársaság Legfelsőbb Bírósága 2017. március 22-i, 3Sžo/154/2015. számú határozatában kimondta, a közigazgatási szerv a bírság kiszabása során a szankció megelőző (preventív) és büntető (represszív) hatását mérlegelni köteles. ${ }^{29}$ A Szlovák Nemzeti Bank döntései nagyon részletes indokolást tartalmaznak a bírság összegére vonatkozóan, és figyelembe veszik a szankció represszív és preventív szerepét, azzal, hogy a szankció nem eredményezhet a vállalkozásnak likviditási problémákat.

A Nemzeti Bank 2019. december 23-i, NBS1-000-037-987. számú határozatában kimondta, hogy a bírságnak kellőképpen érzékelhetőnek kell lennie a vállalkozás tevékenységi területén, és figyelembe kell venni a vállalkozás könyvelésével kapcsolatos nyilvános információkat. Azt is figyelembe kell vennie, hogy a vállalkozás a tisztességtelen kereskedelmi gyakorlat alkalmazásával a szankcionálási eljárás megkezdése előtt felhagyott-e, továbbá hogy milyen mértékben csökkent a fogyasztók bizalma a pénzügyi piac szereplöivel szemben a tisztességtelen kereskedelmi gyakorlat miatt.

A Nemzeti Bank 2019. január 28-i NBS1-000-027-223 sz. határozatában kimondta, hogy az arányosság a bírság tekintetében nem azt jelenti, hogy a fogyasztónak okozott esetleges károk és a bírság összege között matematikai egyenlőség kell, hogy fennálljon. Ez ugyanis a vállalkozásokat spekulációra ösztönözheti. Másrészről azonban a tisztességtelen kereskedelmi gyakorlatok

28 Annual report of the National Bank of Slovakia, 2018. Elérhető: https://www.nbs.sk/_img/Documents/_ Publikacie/AnnualReport/ARNBS18.pdf(letöltés dátuma: 2020.03.18.)

29 Mutatis mutandis a Pozsonyi Regionális Bíróság 2019. június 19-i, 2S/27/2017. számú ítélete. 


\section{TisZTESSÉGTELEN KERESKEDELMI GYAKORLATOK - SZLOVÁKIA}

eredményeként a vállalkozásnál keletkezett vagyoni előny összege nem döntő jelentőségű a bírság összegének megállapítása során.

\subsection{Együttmúködés más tagállamok hatóságaival}

Határokon átnyúló fellépés esetén az SzFvt. 25. \$ (1) bekezdés b) pontja szerint az Európai Bizottság által vezetett jegyzékben szereplő szervezetek jogosultak ideiglenes intézkedést kérni, vagy javaslatot tenni a polgári jogi eljárás kezdeményezésére. A szlovák fogyasztói szervezeteknek nincs tapasztalatuk a határokon átnyúló, a fogyasztók kollektív érdekeinek védelmére irányuló intézkedések terén. Az igazgatási szervek azonban hangsúlyt fektetnek a nemzeti hatóságok közötti határokon átnyúló együttműködés erősítésére. A Szlovák Kereskedelmi Felügyelet 2019-es éves jelentése szerint a szlovák hatóság 17 esetben kérte más tagállamok hatóságának a közreműködését (5 esetben információszolgáltatási és 6 végrehajtási kérelem). A Szlovák Kereskedelmi Felügyelet, mint megkeresett hatóság jelenleg egy aktív esetet regisztrált, Franciaországból. A Szlovák Kereskedelmi Felügyelet megállapította, hogy a 2005/29/EK irányelv és a fogyasztói jogokról szóló 2011/83/EU irányelv ${ }^{30}$ megsértése továbbra is hosszú távú problémát jelent a határokon átnyúló fogyasztói-gazdasági érdekek védelmének területén. ${ }^{31} \mathrm{~A}$ fogyasztókat a határokon átnyúló kapcsolatokban két komoly probléma érinti, egyrészt, a tapasztalat és megértés hiánya, másrészt, a belföldi és a külföldi szolgáltatók közötti különbségtétel.

\subsection{A Fogyasztói Szerződések Feltételeinek és a Tisztességtelen Kereskedelmi Gyakorlatok Értékelésének Bizottsága mint különleges hatóság}

Fontos megemlíteni a Szlovák Köztársaságban működő külön testületet a Fogyasztói Szerződések Feltételeinek és a Tisztességtelen Kereskedelmi Gyakorlatok Értékelésének Bizottságát -, amelyet az SzFvt. 26a. \$-a hozott létre. Ez a hatóság a Szlovák Köztársaság Igazságügyi Minisztériumának része.

30 Az Európai Parlament és a Tanács 2011/83/EU irányelve (2011. október 25.) a fogyasztók jogairól, a 93/13/ EGK tanácsi irányelv és az 1999/44/EK európai parlamenti és tanácsi irányelv módosításáról, valamint a 85/577/EGK tanácsi irányelv és a 97/7/EK európai parlamenti és tanácsi irányelv hatályon kívül helyezéséről, HL L 345., 2017.12.27., 1-26.

31 Annual report of the Slovak Trade Inspection, i.m. 2019, 28. 
A fent említett bizottság megvizsgálja, hogy a vállalkozás alkalmaz-e valamilyen tisztességtelen kereskedelmi gyakorlatot, és ha igen, a bizottság továbbítja megállapításait az illetékes álla mi hatóságoknak, vagy kapcsolatba lép a fogyasztói szervezetekkel, hogy fellépésre ösztönözze őket az illetékes állami hatóságnál. A bizottság a fogyasztókat is segíti, akik állásfoglalást kérhetnek a bizottságtól, amely bár joghatással nem rendelkezik, de felhasználható bizonyítékként bíróság előtt. A bizottság nem rendelkezik döntéshozatali hatáskörrel. A bizottság által kiadott állásfoglalások indokolását gyakran említik a bírósági határozatok vagy a nemzeti hatóságok fogyasztói ügyekben hozott határozat indokolásában, meggyőző megfogalmazásuknak köszönhetően (például a Szlovák Kereskedelmi Felügyelet 2014. március 11-i SK/0215/99/2014. számú határozata, vagy a Kassai I. Kerületi Bíróság, 2014. június 4-i, 39C/448/2009. számú határozata).

Sajnos azonban jelenleg a bizottság nem működik egy nagyvállalkozással folyamatban lévő peres eljárás miatt, amelynek kimenetele alapvető jelentőségű lehet a bizottság jövőbeli tevékenysége szempontjából. ${ }^{32}$

\section{Az üzleti szektor önszabályozása}

Az SzFvt. 10. \$-a értelmében a tisztességtelen kereskedelmi gyakorlatok alkalmazását a kódex megalkotója, valamint a kódex megalkotója közvetítésével más személyek és szövetségek is ellenőrizhetik. Az ilyen tevékenységeket bírósági vagy közigazgatási eljárásoktól függetlenül lehet elvégezni.

Példaként említhetjük a Szlovákiai Ingatlanügynökségek Országos Szövetségének etikai kódexét, ${ }^{33}$ de meglehetősen sikeresönszabályozó intézkedések köszönhetők a Reklámszabályozási Tanács tevékenységének is. ${ }^{34}$ Ez utóbbi célja, hogy előmozdítsa és biztosítsa az őszinte, tisztességes, jogszerü és valósághü reklámot a Szlovák Köztársaságban. A Tanács egyik belső dokumentuma a reklámozási gyakorlat etikai kódexe, amely végrehajtásának felelős szerve a Választottbírósági Bizottság, amelyhez bármely jogi vagy természetes személy panaszt nyújthatja be, a Választottbírósági Bizottság tagjait kivéve.

32 Információ elérhető itt: https://www.justice.gov.sk/Stranky/Ministerstvo/Komisia-na-posudzovanie-podmienokv-spotrebitelskych-zmluvach/Oznamy-o-staznostiach-spotrebitelov-detail.aspx?Ic=284 (letöltés dátuma: 2020.03.15.)

33 Elérhető: https://www.narks.sk/wp-content/uploads/2014/11/eticky-kodex-narks.pdf (letöltés dátuma: 2020.03.15.)

$34 \mathrm{Az}$ angol nyelvü honlap elérhető itt: http://www.rpr.sk/en 


\section{TisZTESSÉGTELEN KERESKEDELMI GYAKORLATOK - SZLOVÁKIA}

A Választottbírósági Bizottság határozatai gyakran foglalkoznak a tisztességtelen kereskedelmi gyakorlatok és a megtévesztő hirdetések egyes aspektusaival.

\section{A bírói és a közigazgatási jogvédelem kapcsolata}

Kérdéses, hogy a közigazgatási szervek (a Szlovák Kereskedelmi Felügyelet és a Szlovák Nemzeti Bank) határozatai a fogyasztók kollektív érdekei esetén befolyásolják-e a bíróságok határozatait. A felügyeleti hatóságok felügyeleti tevékenységet látnak el és bírságot szabnak ki, de a fogyasztók jogairól nem döntenek (a bíróságoktól eltérően). A felügyeleti hatóságok arról döntenek, hogy közigazgatási szabálysértés történt-e avagy sem. Csach szerint azonban, ha a közigazgatási hatóság tisztességtelennek ítéli a kereskedelmi gyakorlatot (és például bírságot szab ki), a határozat a bíróság számára kötelező. ${ }^{35}$ A fenti következtetés megkérdőjelezhető, és a legtöbb jogász szemében az igazságszolgáltatás a végrehajtói hatalomtól független. Csach következtetése talán elfogadható a bíróságok és a közigazgatási szervek hatáskörének nem egyértelmü elkülönítése esetén az absztrakt vizsgálat vonatkozásában. A törvény nem oldja fel kifejezetten a bíróságok és a közigazgatási hatóságok joghatósága közötti, a fogyasztói ügyek absztrakt ellenőrzésével kapcsolatos összeütközéseket. ${ }^{36}$

Ugyanakkor, a közigazgatási szerveknek a fogyasztók kollektív érdekeivel kapcsolatos (absztrakt vizsgálat keretében hozott) határozatai az egyedi jogvitában eljáró bíróságokat nem kötik. A bíróságok természetesen figyelembe vehetik a nemzeti hatóságok absztrakt ellenőrzés keretében hozott megállapításait. Ebben az összefüggésben rámutathatunk a Tt. 747/2004. számú, a pénzügyi piac felügyeletéről szóló törvényre. Ez a törvény a Szlovák Nemzeti Bank felügyeletének általános elvei között kimondja: „A felügyelt szervezetek felügyelete nem terjed ki a felügyelt szervezetek és ügyfeleik közötti jogviszonyokból fakadó viták rendezésére; az ilyen vitákat az illetékes bíróságok vagy más hatóságok az irányadó jogszabályi rendelkezésekkel összhangban tárgyalják és bírálják el." ${ }^{37}$ Amint

35 K. Csach: Nesúdna ingerencia do zmlúv a možnosti jej súdnej korekcie. In: Ingerencia súdov do súkromnoprávnych zmlúv. Zásahy súdov do obsahu súkromnoprávnych zmlúv. Justičná akadémia SR, Pezinok, 2014, 52-66. Elérhető: https://www.ja-sr.sk/files/2014_Zbornik_CSPD_Omsenie_Final_WEB.pdf (letöltés dátuma: 2020.02.15.)

36 Lásd még M. Maslák: Kolektívne záujmy spotrebitelov. In: M. Lenhart et al (eds.): Bratislava Legal Forum 2016. Collective Redress. Univerzita Komenského v Bratislave, Právnická fakulta, Bratislava, 2016, 55-63., elérhető:

https://www.flaw.uniba.sk/fileadmin/praf/Veda/Konferencie_a_podujatialbpf_2016/Zbornik_BPF2016_ sekcia_07.pdf (letöltés dátuma: 2020.02.15.)

37 Tt. 747/2004., 2. $\$(3)$ bekezdés. 
azt a Szlovák Nemzeti Bank a 2019. október 1-jei, NBS1-000-036-210. számú határozatában megállapította, nincs hatásköre egyes jogviták eldöntésére. Ez a nemzeti hatóság, mint említettük, a pénzügyi szektorban működő vállalkozók tevékenységét felügyeli, valamint absztrakt vizsgálatot folytat le.

Összegzésként elmondható, hogy a közigazgatási bírság és más szankciók alkalmazásának lehetősége bizonyos esetekben hatékonyabb ösztönző a jogkövetésre, mint a hosszabb és költségesebb bírósági eljárás. A Szlovák Köztársaságban a nemzeti hatóságok vagy a bíróságok gyakorlatában a fogyasztókkal szembeni tisztességtelen kereskedelmi gyakorlattal szembeni fellépés gyakori és rendszeresen alkalmazott eljárástípus. 


\section{TisZTESSÉGTELEN KERESKEDELMI GYAKORLATOK - SZLOVÁKIA}

\section{Forrásjegyzék}

1. M. BudjAČ: Nekalé obchodné praktiky ako potenciálny zdroj a akcelerátor sústavného používania neprijatelných zmluvných podmienok a ich vplyv na platnosṫ spotrebitel'skej zmluvy. In: G. Urbanská (ed.): Ingerencia súdov do súkromnoprávnych zmlúv: Zásahy súdov do kontraktačného procesu. Justičná akadémia SR, Pezinok, 2013, 109-124.

2. K. Csach: Nesúdna ingerencia do zmlúv a možnosti jej súdnej korekcie. In: Ingerencia súdov do súkromnoprávnych zmlúv. Zásahy súdov do obsahu súkromnoprávnych zmlúv. Justičná akadémia SR, Pezinok, 2014, 52-66., elérhető: https://www.ja-sr.sk/files/2014_Zbornik_CSPD_Omsenie_Final_ WEB.pdf(letöltés dátuma: 2020.02.15.)

3. R. Dobrovodský: Test nekalosti správania sa podnikatelov k spotrebitelom $\mathrm{v}$ slovenskom práve. In: G. Urbanská (ed.): Ingerencia súdov do súkromnoprávnych zmlúv: Zásahy súdov do kontraktačného procesu. Justičná akadémia SR, Pezinok, 2013, 125-152.

4. M. Maslák: Kolektívne záujmy spotrebitelov. In: M. Lenhart et al (eds.): Bratislava Legal Forum 2016. Collective Redress. Univerzita Komenského v Bratislave, Právnická fakulta, Bratislava, 2016, 55-63., elérhető: https://www.Alaw.uniba.sk/fileadmin/praf/Veda/Konferencie_a_ podujatialbpf_2016/Zbornik_BPF2016_sekcia_07.pdf (letöltés dátuma: 2020.02.15.)

5. M. Maslák: Úskalia erga omnes účinkov rozsudku v konaní o abstraktnej kontrole v spotrebitelských veciach. Súkromné právo. Vol. 3, 2017/3. 103-112.

6. P. MÉszáros: Uznesenie Najvyššieho súdu SR sp. zn. 6 Cdo 27/2018 z 28.3.2019 (charakter žaloby o posúdenie neprijatel'nosti podmienky v spotrebitel'ských zmluvách). Súkromné právo, 2019/3.

7. A. Slezáková, P. Mikloš: Zákon o dohlade nad finančným trhom-komentár. Wolters Kluwer, Bratislava, 2018.

8. M. ŠTevČEK et al. (eds.): Občiansky zákonník I. S 1 - 450. Komentár. C. H. Beck, Prague, 2015.

9. D. Zavadová: Konanie o abstraktnej kontrole v spotrebitel'ských veciach. Súkromné právo, 2017/1. 22-28. 
10. Az Európai Parlament és a Tanács 2011/83/EU irányelve (2011. október 25.) a fogyasztók jogairól, a 93/13/EGK tanácsi irányelv és az 1999/44/EK európai parlamenti és tanácsi irányelv módosításáról, valamint a 85/577/ EGK tanácsi irányelv és a 97/7/EK európai parlamenti és tanácsi irányelv hatályon kívül helyezéséről, $H L$ L 345., 2017.12.27., 1-26.

11. Tt. 40/1964. sz. törvény a Polgári Törvénykönyvről

12. Tt. 71/1992 sz. törvény

13. Tt. $128 / 2002$. sz. törvény a belső piac fogyasztók ügyeit érintő állami ellenőrzéséről

14. Tt. 747/2004. sz. a pénzügyi piac felügyeletéről

15. Tt. 300/2005 sz. törvény a büntető törvénykönyvről

16. Tt. 250/2007 sz. törvény a fogyasztóvédelemről

17. Tt. 102/2014. sz. törvény a termékek és szolgáltatások távollevők közötti és üzlethelyiségen kívüli értékesítéséről

18. Tt. 160/2015. sz. törvény a polgári perrendtartásról

19. Európai Unió Bíróságának C-435/11. sz. CHS Tour Services GmbH kontra Team4 Travel GmbH ügyben 2013. szeptember 19-én hozott ítélete (ECLI:EU:C:2013:574)

20. Szlovák Alkotmánybíróság PLz. ÚS 5/2015. sz. 2015. november 18-án hozott határozata

21. Legfelsőbb Bíróság 2017. július 26-án hozott, 7 Ndc 9/2017. sz. ítélete

22. Legfelsőbb Bíróság 2019. március 28-án hozott 6 Cdo. 27/2018. sz. ítélete

23. Legfelsőbb Bíróság 2017. március 22-én hozott 3Sžo/154/2015. sz. ítélete

24. Kassai I. Kerületi Bíróság, 2014. június 4-én hozott 39C/448/2009. sz. ítélete

25. Pozsonyi Regionális Bíróság 2019. január 31-én hozott 14C/4/2016. sz. ítélete

26. Pozsonyi Regionális Bíróság 2019. június 19-én hozott, 2S/27/2017. sz. ítélete

27. Pozsonyi IV. kerületi Bíróság a 2014. szeptember 3-án hozott, 5C/64/2009. sz. ítélete

28. Popradi Kerületi Bíróság 2011. december 20-i 17C/113/2010. sz. ítélete

29. Nitrai (Nyitrai) Járásbíróság 2014. április 1-én hozott, 15C/55/2013. sz. ítélete

30. Szlovák Nemzeti Bank 2019. január 28-én hozott NBS1-000-027-223 sz. határozata 


\section{TisZTESSÉGTELEN KERESKEDELMI GYAKORLATOK - SZLOVÁKIA}

31. Szlovák Nemzeti Bank 2019. május 30-án hozott NBS1-000-037-870. sz. határozata

32. Szlovák Nemzeti Bank 2019. október 1-én hozott NBS1-000-036-210. számú határozata

33. Szlovák Nemzeti Bank 2019. december 23-án kelt NBS1-000-037-987. számú határozata

34. Decision of the National Bank of Slovakia dated 28 January 2019, no. NBS1-000-027-223.

35. Szlovák Kereskedelmi Felügyelet 2014. március 11-én hozott SK/0215/99/2014. sz. határozata

36. Szlovák Kereskedelmi Felügyelet 2016. július 22-án hozott, 2069/04/2016. sz. ideiglenes intézkedése

37. AzEurópaiBizottságSWD (2016) 163.számúszolgálatimunkadokumentuma a tisztességtelen kereskedelmi gyakorlatokról szóló 2005/29/EK irányelv végrehajtásához és alkalmazásához

38. Annual report of the National Bank of Slovakia, 2018., elérhető: https:// www.nbs.skl_img/Documents/_Publikacie/AnnualReport/ARNBS18.pdf (letöltés dátuma: 2020.03.18.)

39. Annual report of the Slovak Trade Inspection, 2016., elérhető: https:// www.soi.sk/sk/Kontrolna-cinnost/Vyrocne-spravy.soi (letöltés dátuma: 2020.03.10.)

40. Annual report of the Slovak Trade Inspection, 2019., elérhetö: https:// www.soi.sk/sk/Kontrolna-cinnost/Vyrocne-spravy.soi (letöltés dátuma: 2020.03.10.)

41. https://www.noviny.sk/slovensko/173558-hechter-musi-zaplatit-pokutu-66000-eur (letöltés dátuma: 2020.03.10.)

42. https://www.sospotrebitelov.sk/sos/soi-firma-vymahala-pohladavkyvyhraznymi-sms-spravami/ (letöltés dátuma: 2020.03.10.)

43. https://www.justice.gov.sk/Stranky/Ministerstvo/Komisia-na-posudzovaniepodmienok-v-spotrebitelskych-zmluvach/Oznamy-o-staznostiachspotrebitelov-detail.aspx?Ic=284 (letöltés dátuma: 2020.03.15.)

44. https://www.narks.sk/wp-content/uploads/2014/11/eticky-kodex-narks.pdf (letöltés dátuma: 2020.03.15.)

45. https://www.soi.sk/en/SOI.soi

46. https://www.nbs.sk/en/consumer 
47. http://www.urso.gov.sk/?language=en

48. https://www.teleoff.gov.sk/regulatory-authority-for-electronic-communicationsand-postal-services/

49. http://www.rpr.sk/en 
Dr. Marek Maslák PhD., a szlovák Nagyszombati (Trnava-i) Egyetem Jogi Kar Polgári és Kereskedelmi Jogi Tanszékének munkatársa, ahol a polgári perrendtartás, a fogyasztóvédelmi-és ingatlanjog a kutatási területe. Rendszeresen publikál hazai és külföldi szakmai folyóiratokban. Az ingatlanjogi törvénnyel kapcsolatos kommentár (Wolters Kluwer, 2019) föszerkesztője, valamint a fogyasztóvédelmi választottbírósági eljárásról szóló törvénnyel kapcsolatos kommentár (Wolters Kluwer, 2017) szerkesztője. A rendszeresen megjelenő Szlovák Ügyvédek Lapja folyóiratban publikált cikkeiért több díjat is kapott. Ö vezeti a Trnava-i Polgári Jogi Jogklinikát, ahol a felügyelete alatt álló joghallgatók ingyenesen, nem kötelező erejű jogi tanácsadást nyújtanak, és amelyek célja egyrészről a lakosság segítése a jogi kérdésekben, másrészről az ügyek lehetőségeinek a feltárása, azaz, hogy milyen módon lehet az adott problémát kezelni és hogy hova lehet fordulni további jogi segítségért. Egyúttal ügyvédjelölt a Nagyova Tenkac (s.r.o.) ügyvédi irodában. 